\title{
Perilaku Belajar, Minat Belajar dan Tingkat Pemahaman Akuntansi dengan Pembelajaran Daring sebagai Variabel Mediasi
}

\author{
Made Swari Praba Waloka ${ }^{1}$ \\ Fakultas Ekonomi dan Bisnis \\ Universitas Udayana, Indonesia
}

\author{
Gede Juliarsa² \\ Fakultas Ekonomi dan Bisnis \\ Universitas Udayana, Indonesia
}

\begin{abstract}
Surel : prabawaloka1999@gmail.com ABSTRAK

Penelitian ini bertujuan untuk mengetahui pengaruh perilaku belajar dan minat belajar terhadap tingkat pemahaman akuntansi serta peran pembelajaran daring dalam memediasi pengaruh perilaku belajar dan minat belajar terhadap Tingkat Pemahaman Akuntansi. Penelitian ini dilakukan di Fakultas Ekonomi dan Bisnis Universitas Udayana. Teknik pengambilan sampel yang digunakan yaitu metode purposive sampling, jumlah sampel yang diperoleh yaitu sebanyak 90 sampel. Teknik analisis yang digunakan adalah analisis jalur. Berdasarkan hasil analisis ditemukan bahwa perilaku belajar tidak berpengaruh signifikan terhadap tingkat pemahaman akuntansi mahasiswa. Minat belajar dan pembelajaran daring berpengaruh signifikan terhadap tingkat pemahaman akuntansi. Pembelajaran daring secara signifikan mampu memediasi pengaruh perilaku belajar dan minat belajar terhadap tingkat pemahaman akuntansi mahasiswa.
\end{abstract}

Kata Kunci: Perilaku Belajar; Minat Belajar; Pembelajaran Daring; Tingkat Pemahaman Akuntansi.

\section{Learning Behavior, Learning Interest and Level of Accounting Understanding with Online Learning as a Mediation Variable}

\section{ABSTRACT}

This study aims to determine the effect of learning behavior and interest in learning on the level of understanding of accounting and the role of online learning in mediating the influence of learning behavior and interest in learning on the level of accounting comprehension. This research was conducted at the Faculty of Economics and Business, Udayana University. The sampling technique used was purposive sampling method, the number of samples obtained was 90 samples. The analysis technique used is path analysis. Based on the results of the analysis, it was found that learning behavior had no significant effect on the level of accounting understanding of students. Interest in learning and online learning has a significant effect on the level of accounting understanding. Online learning is significantly able to mediate the effect of learning behavior and interest in learning on the level of accounting understanding of students.

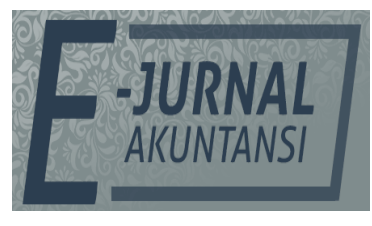

e-ISSN 2302-8556

Vol. 31 No. 10

Denpasar, Oktober 2021

Hal. 2542-2555

DOI:

10.24843/EJA.2021.v31.i10.p11

PENGUTIPAN:

Waloka, M.S.P., \& Juliarsa, G. (2021). Perilaku Belajar, Minat Belajar dan Tingkat

Pemahaman Akuntansi dengan Pembelajaran Daring sebagai Variabel Mediasi. EJurnal Akuntansi, 31(10), 2542-2555

RIWAYAT ARTIKEL: Artikel Masuk: 25 Januari 2021 Artikel Diterima: 31 Maret 2021

Keywords: Learning Behavior; Learning Interest; Online Learning; Accounting Understanding.

Artikel dapat diakses : https://ojs.unud.ac.id/index.php/Akuntansi/index 


\section{PENDAHULUAN}

Pada pendidikan akuntansi tingkat perguruan tinggi memiliki tujuan untuk mendidik mahasiswa agar mahasiswa tersebut memiliki pengetahuan yang baik mengenai akuntansi dan dapat menghasilkan mahasiswa yang berkompeten sebagai seorang akuntan profesional. Mahasiswa yang menempuh pendidikan akuntansi saat ini diharapkan tidak hanya memiliki kemampuan dalam bidang akademik, namun juga mumpuni dalam kemampuan bidang humanistic skill (kemampuan menghadirkan diri secara manusiawi dalam kehidupan masyarakat yang turut bertanggungjawab bagi kelangsungan nilai-nilai kemanusiaan dan kemasyarakatan) dan bidang professional skill (kemampuan melaksanakan profesinya dengan berbekal pengetahuan akademik yang memadai dalam rangka mengaktualisasikan dirinya di masyarakat) sehingga mahasiswa dapat memiliki nilai tambah untuk bersaing dalam dunia kerja. Dewasa ini banyak lulusan akuntansi yang tidak mampu bersaing secara maksimal dalam dunia kerja karena tidak memiliki professional skill atau nilai tambah dalam dirinya. Untuk dapat memiliki pengetahuan akademik dan nilai tambah yang memadai diperlukan pemahaman akuntansi yang baik. Perilaku belajar seorang mahasiswa dapat mempengaruhi tingkat pemahaman akuntansi yang baik. Perilaku belajar mahasiswa berkaitan dengan penggunaan waktu yang baik untuk belajar maupun kegiatan diluar belajar (Narindra \& Budiasih, 2018). Menurut Rokhana \& Sutrisno (2016) minat belajar mahasiswa yang baik yaitu apabila seorang mahasiswa memiliki kesadaran akan tanggung jawab mereka sebagai seorang mahasiswa, sehingga mereka mampu untuk meningkatkan motivasi dan disiplin diri untuk mencapai target yang diinginkan dalam memahami materi yang berhubungan dengan akuntansi.

Pembelajaran secara daring diselenggarakan menggunakan jaringan internet, artinya bahwa penggunaan pembelajaran daring melibatkan unsur teknologi sebagai sarana dan jaringan internet sebagai sistem (Alessandro, 2018). Pelaksanaan pembelajaran dengan sistem daring membutuhkan ketersediaan fasilitas penunjang, seperti smartphone, laptop/notebook dan tablet yang dapat digunakan untuk mengakses informasi dimanapun dan kapanpun (Gikas \& Grant, 2013). Penggunaan teknologi modern memunculkan adanya pembelajaran jarak jauh dan penggunaan teknologi mendorong adanya inovasi yang lebih besar dalam menerapkan sistem pembelajaran di dalam dan di luar kelas (Almeida \& Simoes, 2019). Dengan diterapkannya pembelajaran daring mahasiswa dapat belajar dimanapun dan kapanpun.

Menurut Milman (2015) penggunaan teknologi digital dapat memungkinkan mahasiswa dan dosen melaksanakan proses pembelajaran walaupun mereka ditempat yang berbeda. Pembelajaran daring juga memberikan sebuah manfaat yaitu tersedianya akses belajar bagi mahasiswa, sehingga dapat mengurangi hambatan secara fisik bagi mahasiswa untuk belajar dalam ruang lingkup kelas (Ahmed, 2018). Pemahaman akuntansi dijadikan sebagai tolok ukur yang utama untuk mengetahui keberhasilan seseorang dalam bidang akuntansi (Narindra \& Budiasih, 2018). Adapun tujuan dari mata kuliah akuntansi yaitu dapat memberikan kemampuan dan keterampilan dalam mencatat, menggolongkan, mengikhtisarkan pada sebuah unit usaha yang terjadi pada periode tertentu serta kemampuan menginterpretasikan informasi yang berasal 
dari laporan keuangan tersebut (Zaelani \& Margunani, 2016). Pada dasarnya pendidikan akuntansi dianggap sulit untuk dipelajari oleh beberapa pihak termasuk mahasiswa akuntansi itu sendiri yang juga merasa sulit untuk memahami akuntansi (Zulhawati \& Ariani, 2017).

Hasil penelitian terdahulu yang dilakukan oleh Rokhana \& Sutrisno (2016) menunjukkan bahwa perilaku belajar dan minat belajar memiliki pengaruh positif dan berpengaruh signifikan terhadap tingkat pemahaman akuntansi. Hasil penelitian yang dilakukan oleh Parauba (2014) menunjukkan hasil bahwa perilaku belajar secara signifikan tidak memiliki pengaruh terhadap tingkat pemahaman akuntansi. Berbagai hasil dari penelitian terdahulu, masih terdapat kesenjangan hasil penelitian (research gap) yang berbeda mengenai faktor- faktor yang mempengaruhi tingkat pemahaman akuntansi. Penelitian ini memfokuskan pada variabel pembelajaran daring sebagai variabel mediasi dan pemahaman akuntansi sebagai variabel terikat.

Penelitian ini menggunakan variabel pembelajaran daring sebagai variabel mediasi karena penelitian ini ingin mengetahui adanya peningkatan atau penurunan tingkat pemahaman akuntansi pada mahasiswa dengan menggunakan indeks prestasi kumulatif mahasiswa sebelum dan sesudah pembelajaran daring. Penelitian ini menggunakan Theory of Planned Behavior (TPB), dimana teori ini digunakan untuk menjelaskan mengenai perilaku seseorang yang dipengaruhi oleh niat orang tersebut dalam membentuk perilakunya. Ajzen (1991) menambahkan konstruk yang belum ada dalam Theory of Reasoned Action (TRA) yaitu, kontrol perilaku yang dipersepsi (perceived behavioral control). Konstruk ini ditambahkan untuk memahami keterbatasan yang dimiliki oleh individu dalam membentuk perilaku tertentu. Menurut Ajzen (2001)Theory of Planned Behavior menyebutkan bahwa niat merupakan fungsi dari tiga determinan dasar, yaitu sikap berperilaku (attitude toward the behavior), norma subjektif (subjective norm), persepsi pengendalian perilaku (perceived behavioral control)

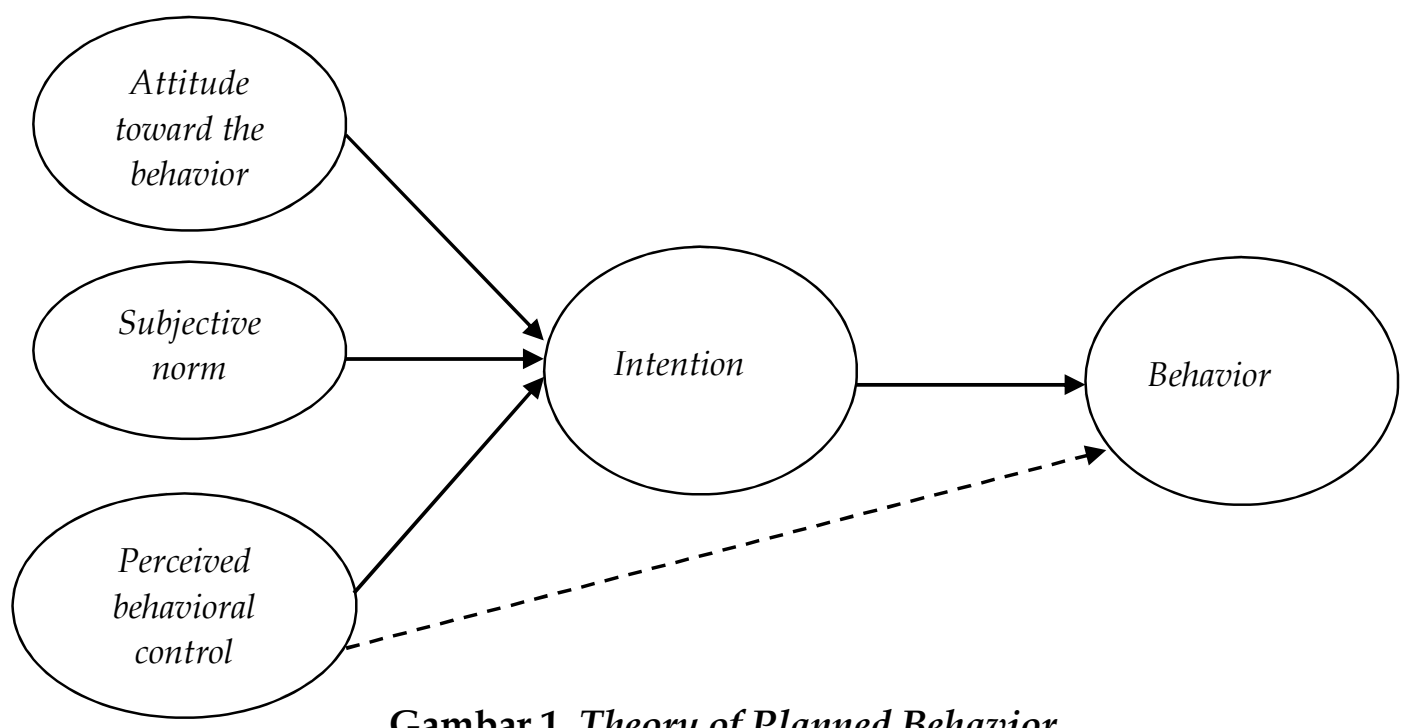

Sumber: Ajzen \& Icek, 1991 
Perilaku belajar dalam penelitian ini menjelaskan mengenai perubahan tingkah laku seseorang dalam melakukan kegiatan proses belajar, yang disebabkan oleh pengalaman yang berulang-ulang dalam situasi dan perubahan perilaku yang tidak bisa dijelaskan atas dasar kecenderungan respons pembawaan, kematangan atau keadaan sesaat seseorang (Afif \& Kaharuddin, 2015). Penelitian yang dilakukan oleh Narindra \& Budiasih (2018) bahwa perilaku belajar berpengaruh signifikan terhadap pemahaman akuntansi. Penelitian lain yang dilakukan oleh Alifah et al., (2019) dan Agung Kresnandra (2019) menunjukkan hasil bahwa perilaku belajar berpengaruh signifikan terhadap tingkat pemahaman akuntansi. Berdasarkan uraian tersebut dapat dirumuskan hipotesis pertama yang akan diuji yaitu sebagai berikut.

$\mathrm{H}_{1}$ : Perilaku belajar berpengaruh signifikan terhadap pemahaman akuntansi.

Minat belajar adalah suatu rasa suka dan ketertarikan pada suatu hal atau aktivitas tanpa adanya paksaan yang membuat seseorang memiliki pemahaman lebih terhadap pelajaran yang diminati. Perilaku belajar yang baik yang dimiliki oleh seorang mahasiswa akan menghasilkan tingkat pemahaman akuntansi yang baik bagi mahasiswa itu sendiri (Mulyana \& Kurniawan, 2019). Penelitian yang dilakukan oleh Narindra \& Budiasih (2018) bahwa minat belajar berpengaruh signifikan terhadap pemahaman akuntansi. Penelitian lain yang dilakukan oleh Rokhana \& Sutrisno (2016) dan Zaelani \& Margunani (2016) menunjukkan hasil bahwa minat belajar berpengaruh signifikan terhadap tingkat pemahaman akuntansi. Berdasarkan uraian tersebut dapat dirumuskan hipotesis kedua yang akan diuji yaitu sebagai berikut.

$\mathrm{H}_{2}$ : Minat belajar berpengaruh signifikan terhadap pemahaman akuntansi.

Pembelajaran daring dapat dilakukan kapanpun dan dimanapun tanpa terikat waktu dan tanpa harus bertatap muka secara langsung. Perkuliahan yang dilakukan secara online atau pembelajaran daring merupakan salah satu bentuk pemanfaatan internet yang dapat meningkatkan peran mahasiswa dalam proses pembelajaran. Pembelajaran secara tatap muka yang mempertemukan tenaga pengajar dengan mahasiswa di dalam kelas dianggap sebagai sistem pengajaran tradisional, sehingga dibutuhkan fasilitas pembelajaran yang lebih baik dengan pemanfaatan teknologi informasi menggunakan bantuan internet (Panigrahi et al., 2018). Pemanfaatan teknologi informasi oleh mahasiswa dapat mempermudah akses berbagai informasi yang dapat menunjang kegiatan belajarnya sehingga dapat memiliki pemahaman yang lebih maksimal pada diri mahasiswa tersebut. Penelitian terdahulu yang dilakukan oleh Kuo et al., (2014) menyatakan bahwa pembelajaran daring lebih condong atau berpusat pada mahasiswa, sehingga mahasiswa mampu memiliki tanggung jawab dalam belajar dan mahasiswa dapat memiliki tingkat kemandirian dalam proses belajar. Beberapa penelitian menunjukkan bahwa evaluasi pembelajaran online menghasilkan efektifitas yang signifikan (Baldwin et al., 2017). Berdasarkan uraian tersebut dapat dirumuskan hipotesis ketiga yang akan diuji yaitu sebagai berikut.

$\mathrm{H}_{3}$ : Pembelajaran daring berpengaruh signifikan terhadap pemahaman akuntansi.

Belajar merupakan sebuah proses perubahan perilaku yang didapat melalui pengalaman dan latihan yang dilakukan oleh seseorang, sehingga membuat seseorang yang pada awalnya tidak mengerti menjadi mengerti. Dalam proses pembelajaran diperlukan perilaku belajar yang sesuai dengan tujuan pendidikan, 
dengan adanya perilaku belajar yang baik maka tujuan pendidikan dapat dicapai secara maksimal dan prestasi akademik juga dapat ditingkatkan. Perilaku belajar yang baik akan menghasilkan tingkat pemahaman yang baik, sebaliknya perilaku belajar yang buruk akan menghasilkan tingkat pemahaman yang buruk. Pemahaman akuntansi yang baik sangat di perlukan oleh mahasiswa untuk menambah kemampuannya dalam bersaing di dunia kerja. Perilaku belajar mahasiswa yang baik dalam pelaksanaan pembelajaran daring akan mempengaruhi tingkat pemahaman akuntansi yang baik.Berdasarkan uraian tersebut dapat dirumuskan hipotesis keempat yang akan diuji yaitu sebagai berikut.

$\mathrm{H}_{4}$ : Pembelajaran daring memediasi pengaruh antara perilaku belajar terhadap pemahaman akuntansi.

Minat belajar merupakan suatu rasa suka, ketertarikan dan perhatian terhadap suatu pelajaran. Minat belajar memberikan sesuatu yang positif terhadap pembelajaran akademik, dengan adanya minat belajar yang baik maka akan mendukung mahasiswa untuk meningkatkan pemahaman belajarnya. Minat yang besar akan membuat segala rintangan dapat dihadapi dengan baik, sebaliknya tanpa adanya minat seseorang akan menjadi mudah menyerah. Seseorang yang memiliki minat terhadap suatu pelajaran, maka seseorang tersebut akan rajin belajar dan terus memahami semua ilmu yang berhubungan dengan pelajaran tersebut. Seseorang yang memiliki minat belajar yang tinggi cenderung akan tekun, rajib belajar, semangat dan senang menghadapi tantangan dalam pelajaran tersebut. Seseorang yang memiliki minat belajar yang rendah cenderung akan malas belajar, dan tidak memiliki upaya untuk belajar secara mandiri. Minat belajar yang baik terhadap mata kuliah akuntansi akan membuat seseorang memiliki pengetahuan dan pemahaman akuntansi yang baik. Minat belajar mahasiswa yang baik dalam pelaksanaan pembelajaran daring akan mempengaruhi tingkat pemahaman akuntansi yang baik. Berdasarkan uraian tersebut dapat dirumuskan hipotesis kelima yang akan diuji yaitu sebagai berikut. $\mathrm{H}_{5}$ : Pembelajaran daring memediasi pengaruh antara minat belajar terhadap pemahaman akuntansi.

\section{METODE PENELITIAN}

Penelitian ini menggunakan pendekatan kuantitatif. Pengambilan data-data diperoleh melalui instrument penelitian. Analisis data bersifat kuantitatif yaitu untuk menguji hipotesis yang telah ditentukan. Penelitian ini dilakukan di Fakultas Ekonomi dan Bisnis Universitas Udayana, karena Fakultas Ekonomi dan Bisnis ini bergerak di bidang pendidikan dimana perihal dilakukan penelitian agar mengetahui bagaimana pemahaman akuntansi mahasiswa di kampus tersebut. Objek dalam penelitian ini tingkat pemahaman akuntansi mahasiswa yang dipengaruhi oleh pembelajaran daring, perilaku belajar dan minat belajar. Adapun dalam penelitian ini terdapat variabel bebas yaitu perilaku belajar $\left(X_{1}\right)$ dan minat belajar $\left(\mathrm{X}_{2}\right)$. Variabel terikat yaitu pemahaman akuntansi $(\mathrm{Y})$ dan menggunakan variabel mediasi yaitu pembelajaran (Z). Perilaku belajar merupakan suatu kegiatan belajar yang dilakukan secara berulang dan konsisten untuk mampu memahami suatu pelajaran secara maksimal dan mampu menghasilkan prestasi 
akademik. Adapun indikator pengukuran perilaku belajar yaitu, kebiasaan mengikuti pelajaran, kebiasaan membaca buku dan kebiasaan menghadapi ujian.

Minat belajar didefinisikan sebagai perasaan suka atau ketertarikan mahasiswa terhadap pelajaran yang disukainya, sehingga mendorong mahasiswa untuk berlatih, mempelajari dan menguasai pengetahuan serta pengalaman dengan menunjukkan partisipasi dan keaktifan dalam mencari pengetahuan tersebut. Adapun indikator pengukuran minat belajar yaitu ketertarikan akan mengikuti pembelajaran, konsentrasi yang tinggi terhadap proses pembelajaran, pengetahuan yang luas akan ilmu akuntansi dan kesadaran yang tinggi untuk belajar akuntansi. Menurut Mustofa et al., (2019) metode pembelajaran daring merupakan sistem pendidikan jarak jauh dengan berbagai metode pengajaran dimana terdapat aktivitas pengajaran yang dilaksanakan secara terpisah dari aktivitas belajar. Berbagai jenis platform dapat dimanfaatkan untuk mendukung kegiatan pembelajaran daring (Bensalem, 2018). Platform yang dapat dimanfaatkan untuk menunjang kegiatan pembelajaran lain yaitu pembelajaran daring melalui whatsaap, instagram, youtube, email, google, webex dan zoom. Telah berlangsung sejumlah kursus penulisan online yang terus berkembang di pendidikan tinggi (King et al., 2018). Melalui pembelajaran daring akan tercipta pada sebuah pendidikan tinggi suatu lingkaran belajar modern (Huda et al., 2018). Pembelajaran daring diukur dengan variabel dummy digunakan $(1=$ menggunakan pembelajaran daring, 0 = tidak menggunakan pembelajaran daring). Pemahaman akuntansi adalah usaha yang dimiliki seseorang untuk menjelaskan kembali ilmu yang telah diperoleh dalam bentuk tertulis maupun lisan terhadap orang lain sehingga membuat orang tersebut mengerti dan memahami apa yang sudah disampaikan (Hermawan \& Rochmawati, 2019). Dalam penelitian ini tingkat pemahaman akuntansi diukur melalui IPK yang diperoleh mahasiswa akuntansi regular Denpasar angkatan 2017 Fakultas Ekonomi dan Bisnis Universitas Udayana.

Populasi dalam penelitian ini adalah Mahasiswa Fakultas Ekonomi dan Bisnis Universitas Udayana. Teknik penentuan sampel yang dipilih adalah nonprobability sampling dengan metode purposive sampling dengan tujuan untuk mendapatkan sampel yang sesuai dengan kriteria yang ditentukan. Kriteria sampel adalah mahasiswa angkatan 2017 yang sudah menempuh minimal 120 sks. Sampel yang didapat dalam penelitian ini berjumlah 90 responden. Metode pengumpulan data yang dilakukan dalam penelitian ini adalah dengan metode pengumpulan data primer dengan menggunakan pertanyaan atau pernyataan tertulis berupa kuesioner atau angket terkait dengan pemasalahan yang diteliti. Instrumen yang digunakan dianalisis validitas dan reliabilitas, kemudian dilakukan uji statistik deskriptif, uji asumsi klasik dan uji analisis jalur. Hasil uji analisis jalur berikutnya akan dilakukan uji sobel, uji koefisien determinasi $\left(R^{2}\right)$, uji kelayakan model (Uji F) dan uji hipotesis (Uji t). Persamaan model analisis jalur dalam penelitian ini dapat diformulasikan sebagai berikut.

$\mathrm{Y}={ }_{\mathrm{p}} \mathrm{YX}_{1} \mathrm{X}_{1}+{ }_{\mathrm{p}} \mathrm{YX}_{2} \mathrm{X}_{2}+\varepsilon_{1}$

$\mathrm{Z}={ }_{\mathrm{p}} \mathrm{ZX}_{1} \mathrm{X}_{1}+{ }_{\mathrm{p}} \mathrm{ZX}_{2} \mathrm{X}_{2}+\mathrm{p}_{\mathrm{p}}+\varepsilon$

Keterangan:

$\begin{array}{ll}\mathrm{X}_{1} & : \text { Perilaku Belajar } \\ \mathrm{X}_{2} & : \text { Minat Belajar }\end{array}$




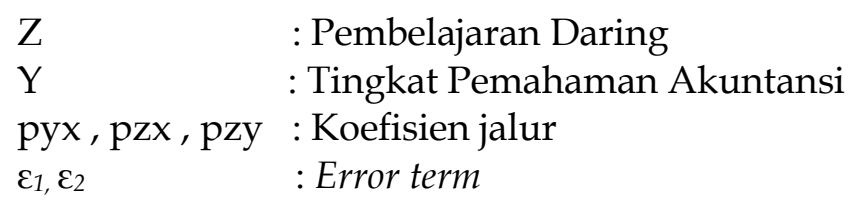

\section{HASIL DAN PEMBAHASAN}

Berdasarkan hasil uji validitas maka dinyatakan bahwa semua indikator pernyataan di dalam kuesioner memiliki nilai koefisien korelasi dengan skor total seluruh item pernyataan lebih besar dari 0,30. Hal ini menunjukkan bahwa butirbutir pernyataan dalam instrument tersebut valid. Berdasarkan hasil uji reliabilitas menunjukkan bahwa seluruh instrument penelitian memiliki koefisien Cronbach's Alpha lebih dari 0,60. Hal ini menunjukkan bahwa, semua instrument reliabilitas sehingga dapat digunakan untuk melakukan penelitian. Dalam penelitian ini, analisis statistik deskriptif digunakan dengan tujuan untuk melakukan analisa data melalui cara menggambarkan data yang telah dikumpulkan sebagaimana adanya, tanpa memiliki maksud untuk menarik kesimpulan yang berlaku umum atau generalisasi. Pada Tabel 1, menunjukkan bahwa jumlah pengamatan $(\mathrm{N})$ penelitian ini berjumlah 90 . Variabel perilaku belajar memiliki nilai minimum sebesar 2,54 dan nilai maksimum sebesar 4,85. Variabel perilaku belajar memiliki nilai mean sebesar 3,87 dan nilai standar deviasi sebesar 0,533. Variabel minat belajar memiliki nilai minimum sebesar 2,33 dan nilai maksimum sebesar 4,89. Variabel minat belajar memiliki nilai mean sebesar 3,874 dan nilai standar deviasi sebesar 0,543 .

Tabel 1. Hasil Statistik Deskriptif

\begin{tabular}{lccccc}
\hline & $\mathrm{N}$ & Minimum & Maximum & Mean & Std. Deviation \\
\hline Perilaku Belajar & 90 & 2,54 & 4,85 & 3,878 & 0,533 \\
Minat Belajar & 90 & 2,33 & 4,89 & 3,874 & 0,543 \\
Valid N & 90 & & & & \\
\hline
\end{tabular}

Sumber: Data Penelitian, 2020

Berdasarkan hasil uji normalitas didapat nilai signifikansi pada model 1 sebesar 0,051 yang lebih besar dari 0,05 dan nilai signifikansi pada model 2 sebesar 0,200 lebih besar dari 0,05. Berdasarkan nilai signifikansi uji Kolmogorov-Smirnov yang lebih dari 0,05 maka dapat disimpulkan bahwa model persamaan berdistribusi normal. Berdasarkan hasil uji multikolinieritas pada kedua model bahwa nilai tolerance pada masing-masing variabel independen dan variabel mediasi lebih besar dari 0,10 dan nilai VIF lebih kecil dari 10. Hal ini berarti model analisis jalur bebas dari gejala multikolinieritas. Berdasarkan hasil uji heteroskedastisitas model 1 nilai signifikansi dari variabel perilaku belajar sebesar 0,439 dan variabel minat belajar sebesar 0,142. Hasil uji heteroskedastisitas model 2 nilai signifikansi dari variabel perilaku belajar sebesar 0,224, variabel minat belajar sebesar 0,225 dan variabel pembelajaran daring sebesar 0,114. Nilai tersebut lebih besar dari 0,05 yang berarti pada hasil model 1 dan 2 tidak terdapat pengaruh antara variabel bebas terhadap absolute residual. Dengan demikian, model yang dibuat tidak mengandung gejala heteroskedastisitas. Dapat diamati hasil dari analisis jalur pada Tabel 2 . 
Tabel 2. Hasil Analisis Jalur 1

\begin{tabular}{|c|c|c|c|c|c|c|}
\hline \multicolumn{2}{|l|}{ Model } & \multicolumn{2}{|c|}{$\begin{array}{l}\text { Unstandardized } \\
\text { Coefficients }\end{array}$} & \multirow{2}{*}{$\begin{array}{l}\text { Standardized } \\
\text { Coefficients } \\
\text { Beta }\end{array}$} & \multirow[b]{2}{*}{$\mathrm{t}$} & \multirow[b]{2}{*}{ Sig. } \\
\hline & & $\mathrm{B}$ & Std.Error & & & \\
\hline \multirow[t]{3}{*}{1} & (Constant) & $-2,287$ & 0,264 & & $-8,665$ & 0,000 \\
\hline & $\begin{array}{l}\text { Perilaku } \\
\text { Belajar }\end{array}$ & 0,390 & 0,171 & 0,414 & 2,283 & 0,025 \\
\hline & $\begin{array}{l}\text { Minat } \\
\text { Belajar }\end{array}$ & 0,326 & 0,168 & 0,352 & 1,942 & 0,045 \\
\hline \multicolumn{2}{|c|}{ Adj. $R$ Square $\left(\mathrm{R}^{2}\right)$} & & 0,564 & & & \\
\hline \multicolumn{2}{|l|}{$F_{\text {hitung }}$} & & 56,367 & & & \\
\hline \multicolumn{2}{|c|}{ Signifikan F } & & 0,000 & & & \\
\hline
\end{tabular}

Sumber: Data Penelitian, 2020

Berdasarkan hasil analisis jalur substruktur 1 maka dapat dibuat persamaan struktural sebagai berikut.

$Z=0,414 X_{1}+0,352 X_{2}+\varepsilon_{1}$

Dapat diperoleh nilai standar error sebagai berikut.

Nilai $\varepsilon_{1}$ :

$\varepsilon_{1}=\sqrt{1}-R^{2}$

$\varepsilon_{1}=\sqrt{1}-0,564$

$\varepsilon_{1}=0,660$

\section{Tabel 3. Hasil Analisis Jalur 2}

\begin{tabular}{|c|c|c|c|c|c|c|}
\hline \multirow[t]{2}{*}{ Model } & & \multicolumn{2}{|c|}{$\begin{array}{l}\text { Unstandardized } \\
\text { Coefficients }\end{array}$} & \multirow{2}{*}{$\begin{array}{l}\text { Standardized } \\
\text { Coefficients } \\
\text { Beta }\end{array}$} & \multirow[b]{2}{*}{$t$} & \multirow[b]{2}{*}{ Sig. } \\
\hline & & $\mathrm{B}$ & $\begin{array}{l}\text { Std. } \\
\text { Error }\end{array}$ & & & \\
\hline \multirow[t]{4}{*}{2} & (Constant) & 3,110 & 0,055 & & 56,968 & 0,000 \\
\hline & $\begin{array}{l}\text { Perilaku } \\
\text { Belajar }\end{array}$ & $-0,009$ & 0,027 & $-0,041$ & $-0,322$ & 0,748 \\
\hline & Minat Belajar & 0,152 & 0,026 & 0,738 & 5,852 & 0,000 \\
\hline & $\begin{array}{l}\text { Pembelajaran } \\
\text { Daring }\end{array}$ & 0,055 & 0,016 & 0,245 & 3,360 & 0,001 \\
\hline \multicolumn{2}{|c|}{ Adj. $R$ Square $\left(R^{2}\right)$} & & 0,801 & & & \\
\hline \multicolumn{2}{|l|}{$\mathrm{F}_{\text {hitung }}$} & & 115,216 & & & \\
\hline \multicolumn{2}{|c|}{ Signifikan F } & & 0,000 & & & \\
\hline
\end{tabular}

Sumber: Data Penelitian, 2020

Berdasarkan hasil analisis jalur substruktur 2 maka dapat dibuat persamaan struktural sebagai berikut.

$Y=-0,041 X_{1}+0,738 X_{2}+0,245 Z+\varepsilon_{2}$

Dapat diperoleh nilai standar error sebagai berikut.

Nilai $\varepsilon_{2}$ :

$\varepsilon_{2}=\sqrt{1}-R^{2}$

$\varepsilon_{2}=\sqrt{1}-0,801$

$\varepsilon_{2}=0,446$ 
Hasil koefisien jalur pada hipotesis penelitian dapat digambarkan pada Gambar berikut.

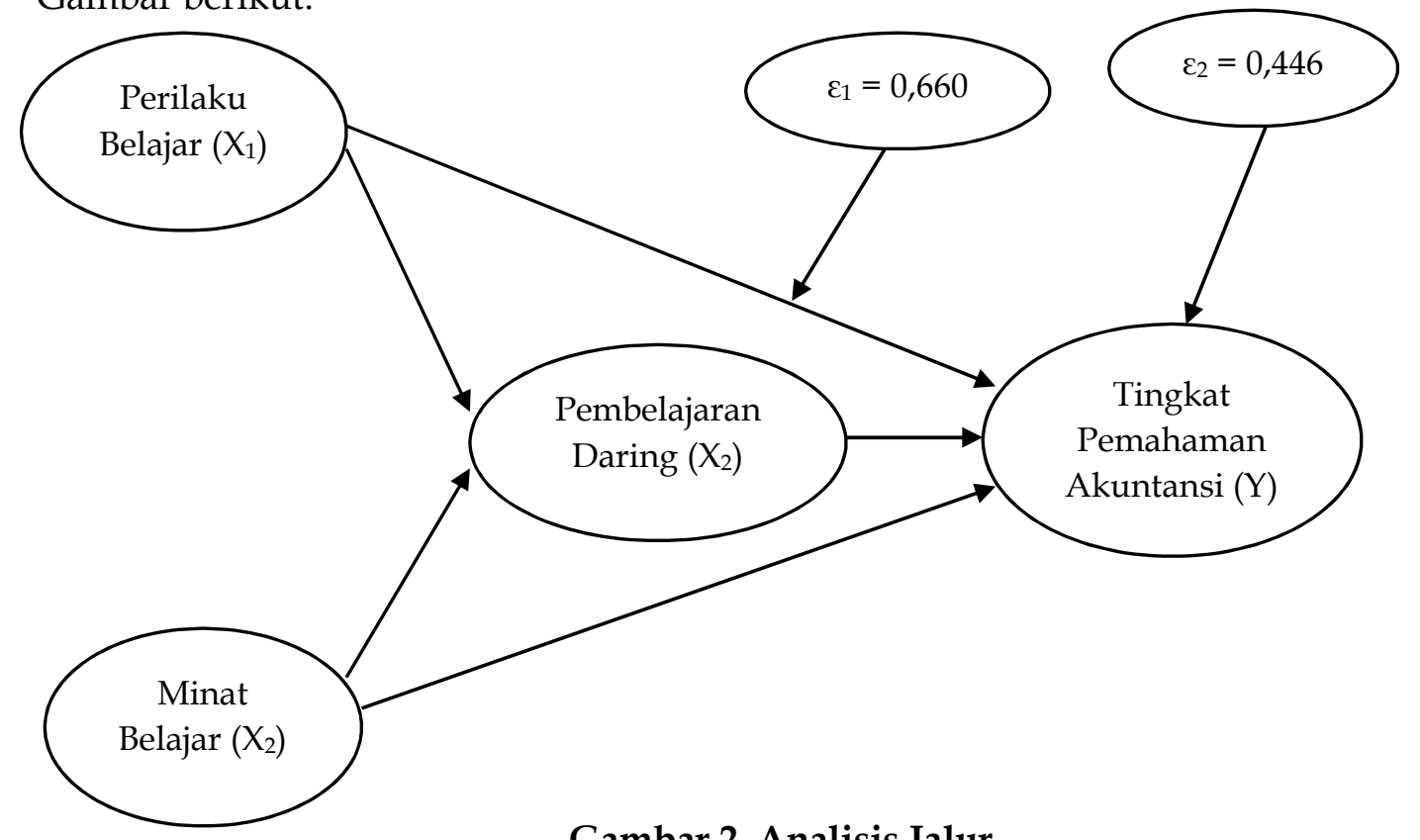

Sumber: Data Penelitian, 2020

Gambar 2. Analisis Jalur

Keterangan:

$\begin{array}{ll}\mathrm{Y} & \text { : Tingkat Pemahaman Akuntansi } \\ \mathrm{Z} & \text { : Pembelajaran Daring } \\ \mathrm{X}_{1} & \text { : Perilaku Belajar } \\ \mathrm{X}_{2} & \text { : Minat Belajar } \\ \mathrm{p} & \text { : Koefisien Garis Jalur } \\ \varepsilon & \text { : error }\end{array}$

Berdasarkan Tabel 2, dan Tabel 3, menunjukkan bahwa nilai koefisien determinasi persamaan analisis jalur model 1 yaitu sebesar 0,564 hal ini berarti 56,4 persen variasi tingkat pemahaman akuntansi dipengaruhi oleh variabel perilaku belajar dan minat belajar sedangkan sisanya sebesar 43,6 persen dijelaskan oleh faktor-faktor lain yang tidak dijelaskan dalam model penelitian. Hasil uji nilai koefisien determinasi persamaan analisis jalur model 2 yaitu sebesar 0,801 hal ini berarti 80,1 persen variasi tingkat pemahaman akuntansi dipengaruhi oleh variabel perilaku belajar, minat belajar dan pembelajaran daring, sedangkan sisanya sebesar 19,9 persen dijelaskan oleh faktor-faktor lain yang tidak dijelaskan dalam model penelitian.

Hasil uji kelayakan model untuk kedua model persamaan analisis jalur menunjukkan bahwa nilai signifikansi uji $\mathrm{F}$ yaitu sebesar 0,000 yang lebih kecil dari $\mathrm{a}=0,05$, ini berarti model persamaan analisis jalur memenuhi syarat uji kelayakan model. Hasil ini memberikan makna bahwa variabel perilaku belajar, minat belajar dan pembelajaran daring dapat atau layak digunakan untuk memprediksi variabel tingkat pemahaman akuntansi mahasiswa Fakultas Ekonomi dan Bisnis Universitas Udayana.

Hasil uji $t$ untuk variabel perilaku belajar menunjukan hasil analisis pengaruh perilaku belajar terhadap tingkat pemahaman akuntansi diperoleh nilai 
signifikansi sebesar 0,748 $>0,05$. Hasil ini mengindikasikan bahwa $\mathrm{H}_{0}$ diterima dan $\mathrm{H}_{1}$ ditolak yang berarti tidak terdapat pengaruh yang signifikan antara Perilaku Belajar $\left(\mathrm{X}_{1}\right)$ terhadap Tingkat Pemahaman Akuntansi $(\mathrm{Y})$. Namun hal ini sejalan dengan penelitian yang dilakukan oleh Parauba (2014) dimana perilaku belajar secara signifikan tidak berpengaruh terhadap tingkat pemahaman akuntansi.

Hasil uji t untuk variabel minat belajar menunjukan hasil analisis pengaruh minat belajar terhadap tingkat pemahaman akuntansi diperoleh nilai signifikansi sebesar 0,000 dengan nilai koefisien beta sebesar 0,738 menunjukkan arah positif. Nilai signifikansi 0,000 $<0,05$ mengindikasikan bahwa $\mathrm{H}_{0}$ ditolak dan $\mathrm{H}_{2}$ diterima yang berarti terdapat pengaruh signifikan antara Minat Belajar $\left(X_{2}\right)$ terhadap Tingkat Pemahaman Akuntansi (Y). Hasil penelitian ini menunjukkan bahwa minat belajar berpengaruh terhadap keberhasilan mahasiswa untuk meningkatkan pemahamannya terhadap akuntansi. Dengan adanya minat belajar yang tinggi maka seorang mahasiswa akan lebih mudah untuk mencapai tujuan pembelajaran. Terdapat dua faktor yang mempengaruhi minat belajar seorang mahasiswa, yaitu faktor dari dalam diri mahasiswa meliputi, motivasi, keingintahuan dan yang lainnya, dan faktor dari lingkungan mahasiswa tersebut meliputi dorongan dari orangtua, tersedianya fasilitas prasarana dan sarana dan keadaan lingkungan.

Hasil uji t untuk variabel pembelajaran daring menunjukan hasil analisis pengaruh pembelajaran daring terhadap tingkat pemahaman akuntansi diperoleh nilai signifikansi sebesar 0,001 dengan nilai koefisien beta sebesar 0,245 menunjukkan arah positif. Nilai signifikansi 0,001 $<0,05$ mengindikasikan bahwa $\mathrm{H}_{0}$ ditolak dan $\mathrm{H}_{3}$ diterima yang berarti terdapat pengaruh signifikan antara Pembelajaran Daring (Z) terhadap Tingkat Pemahaman Akuntansi (Y). Hasil penelitian ini sesuai dengan penelitian yang dilakukan oleh Fadhilatunisa et al., (2020). Shyr \& Chen (2018) mengemukakan bahwa penggunaan teknologi dalam pembelajaran merupakan salah satu strategi untuk dapat membentuk kemandirian mahasiswa dalam menemukan pengetahuan. Pembelajaran daring dapat meningkatkan pemahaman akuntansi mahasiswa karena materi yang disajikan dapat diakses dimanapun dan kapanpun sehingga mahasiswa dapat mengakses materi pembelajaran tanpa adanya keterbatasan waktu. Para pakar mengarahkan bahwa segala sumber daya mesti dikerahkan bagi terciptanya pendidikan online yang memang sedang berlangsung untuk menjadi arus utama pada tahun 2025 (Palvia et al., 2018).

Perhitungan uji sobel untuk pengaruh tidak langsung antara perilaku belajar, minat belajar terhadap tingkat pemahaman akuntansi melalui pembelajaran daring dihitung sebagai berikut. Pembelajaran Daring (Z) Memediasi Pengaruh Perilaku Belajar $\left(X_{1}\right)$ terhadap Tingkat Pemahaman Akuntansi (Y).

$Z=\frac{0,414 \times 0,245}{\sqrt{0,245^{2}} 0,171^{2}+0,414^{2} 0,016^{2}+0,171^{2} 0,016^{2}}$

$Z=2,386$

Berdasarkan hasil perhitungan sobel mendapatkan z sebesar 2,386 >1,96 dengan tingkat signifikansi 5 persen maka hasil ini membuktikan bahwa Pembelajaran Daring (Z) secara signifikan mampu memediasi pengaruh Perilaku 
Belajar $\left(\mathrm{X}_{1}\right)$ terhadap Tingkat Pemahaman Akuntansi (Y). Hasil ini membuktikan Hipotesis 4 terbukti. Dengan perilaku belajar yang lebih baik dapat meningkatkan hasil belajar mahasiswa selama pembelajaran daring, hal ini dapat dilihat melalui peningkatan IPK mahasiswa sebelum dan sesudah menggunakan pembelajaran daring. Sebelum menggunakan pembelajaran daring mahasiswa yang memperoleh IPK sebesar 3,50 -3,60 memiliki presentase sebanyak 14 persen dan perolehan IPK setelah pembelajaran daring memliki presentase sebanyak 20 persen hal tersebut menunjukkan terjadinya peningkatan hasil belajar dengan menggunakan media daring sebesar 6 persen. Penerapan pembelajaran daring dapat memungkinkan mahasiswa mengikuti proses pembelajaran walaupun mahasiswa berada ditempat yang berbeda, sehingga mahasiswa tidak mengalami ketertinggalan materi perkuliahan dan dapat meningkatkan pemahaman akuntansinya. Pembelajaran Daring (Z) Memediasi Pengaruh Minat Belajar $\left(\mathrm{X}_{2}\right)$ terhadap Tingkat Pemahaman Akuntansi $(Y)$.

$Z=\frac{0,352 \times 0,245}{\sqrt{0,245^{2}} 0,168^{2}+0,352^{2} 0,016^{2}+0,168^{2} 0,016^{2}}$

$Z=2,072$

Berdasarkan hasil perhitungan sobel mendapatkan z sebesar 2,072 >1,96 dengan tingkat signifikansi 5 persen maka hasil ini membuktikan bahwa Pembelajaran Daring $(Z)$ secara signifikan mampu memediasi pengaruh Minat Belajar $\left(\mathrm{X}_{1}\right)$ terhadap Tingkat Pemahaman Akuntansi $(\mathrm{Y})$. Hasil ini membuktikan Hipotesis 5 terbukti. Minat merupakan perasaan suka atau ketertarikan terhadap suatu hal sehingga dapat menimbulkan perasaan senang terhadap suatu hal tersebut. Dengan adanya penerapan pembelajaran daring yang memberikan akses kemudahan untuk mendapatkan informasi mengenai pembelajaran maka akan menimbulkan perasaan suka atau ketertarikan dalam proses pembelajaran. Minat belajar yang tinggi dapat meningkatkan hasil pembelajaran, hal ini dapat dilihat melalui peningkatan IPK mahasiswa sebelum menggunakan pembelajaran daring dan sesudah menggunakan pembelajaran daring. Mahasiswa yang memperoleh IPK 3,71-3,80 sebelum pembelajaran daring sebanyak 23 persen dan setelah pembelajaran daring sebanyak 30 persen, hal tersebut membuktikan terjadinya peningkatan perolehan IPK sebesar 7 persen.

\section{SIMPULAN}

Berdasarkan analisis data yang telah diuraikan maka dapat disimpulkan bahwa perilaku belajar tidak berpengaruh signifikan tehadap tingkat pemahaman akuntansi mahasiswa. Minat belajar berpengaruh signifikan terhadap tingkat pemahmanan akuntansi. Pembelajaran daring berpengaruh signifikan terhadap tingkat pemahaman akuntansi. pembelajaran daring mampu memediasi pengaruh perilaku belajar terhadap tingkat pemahaman akuntansi. pembelajaran daring mampu memediasi pengaruh minat belajar terhadap tingkat pemahaman akuntansi.

Berdasarkan hasil analisis dapat disarankan untuk peneliti selanjutnya diharapkan menggunakan responden lebih dari satu angkatan dan dapat menggunakan responde dari universitas lain, di luar Universitas Udayana, agar 
hasil penelitian ini dapat dibandingkan. Peneliti selanjutnya juga diharapkan menambah variabel eksternal seperti lingkungan belajar.

\section{REFERENSI}

Afif, A., \& Kaharuddin, F. (2015). Perilaku Belajar Peserta Didik Ditinjau Dari Pola Asuh Otoriter Orang Tua. Auladuna, 2(2), 287-300.

Agung Kresnandra, A. A. N. (2019). Pengaruh Perilaku Belajar terhadap Tingkat Pemahaman Akuntansi dengan Kecerdasan Emosional sebagai Variabel Pemoderasi. E-Jurnal Akuntansi, 28(3), 2065-2075. https://doi.org/10.24843/eja.2019.v28.i03.p27

Ahmed, R. (2018). Effects of online education on encoding and decoding process of students and teachers. Education Resources Information Center, 7.

Ajzen, I. (1991). The Theory of Planned Behavior Organizational Behavior and Human Decision Processes. Organizational Behavior and Human Decision Processes, 50(2), 179-211.

Ajzen, I. (2001). Nature and Operation of Attitudes. Annual Review of Psychology, $52(1), 27-58$.

Alessandro, B. (2018). Digital skills and competence, and digital and online $\begin{array}{llll}\text { learning. } & \text { European Training } & 72 .\end{array}$ https://www.etf.europa.eu/sites/default/files/2018-10/DSC and DOL_0.pdf

Alifah, S., Narsih, D., \& Widiyarto, S. (2019). Pengaruh Metode Partisipatori Dan Minat Belajar Terhadap Kemampuan Berwirausaha Siswa Smk. Jurnal Pendidikan, 10(1), 66-81.

Almeida, F., \& Simoes, J. (2019). The role of serious games, gamification and industry 4.0 tools in the education 4.0 paradigm. Contemporary Educational Technology, 10(2), 120-136. https:/ / doi.org/10.30935/cet.554469

Baldwin, S., Ching, Y. H., \& Hsu, Y. C. (2017). Online Course Design in Higher Education: A Review of National and Statewide Evaluation Instruments. TechTrends, 62(1), 46-57. https:// doi.org/10.1007/s11528-017-0215-z

Bensalem, E. (2018). The Impact of WhatsApp on EFL students' Vocabulary Learning. Arab World English Journal, 9(1), 23-38. https://doi.org/10.24093/awej/vol9no1.2

Fadhilatunisa, D., Fakhri, M. M., \& Rosidah. (2020). Pengaruh Blended Learning Terhadap Aktivitas Belajar Dan Hasil Belajar Mahasiswa Akuntansi. Jurnal Pendidikan Akuntansi Indonesia, 18(1), 93-106.

Gikas, J., \& Grant, M. M. (2013). Mobile computing devices in higher education: Student perspectives on learning with cellphones, smartphones \& social media. Internet and Higher Education, 19, 18-26. https://doi.org/10.1016/j.iheduc.2013.06.002

Hermawan, R., \& Rochmawati. (2019). Pengaruh Kecerdasan Emosional, Minat Belajar, dan Hasil Belajar Pengantar Akuntansi Terhadap Tingkat Pemahaman Akuntansi Mahasiswa S1 Prodi Pendidikan Akuntansi Fakultas Ekonomi Universitas Negeri Surabaya. Jurnal Pendidikan Akuntansi, 07(1), 109-113. https:/ / doi.org/10.1017/CBO9781107415324.004

Huda, M., Maseleno, A., Teh, K. S. M., Don, A. G., Basiron, B., Jasmi, K. A., Mustari, M. I., Nasir, B. M., \& Ahmad, R. (2018). Understanding Modern Learning 
Environment (MLE) in big data era. International Journal of Emerging $\begin{array}{llll}\text { Technologies in } & \text { Learning, 13(5), }\end{array}$ https://doi.org/10.3991/ijet.v13i05.8042

King, C. S. T., Ryan, C. J., King, C. S. T., Keeth, S., \& Ryan, C. J. (2018). Collaborative Curriculum Design and Assessment: Piloting a Hybrid First-Year Writing Course. Journal of Interactive Online Learning, 16(1), 41-62.

Kuo, Y. C., Walker, A. E., Schroder, K. E. E., \& Belland, B. R. (2014). Interaction, Internet self-efficacy, and self-regulated learning as predictors of student satisfaction in online education courses. Internet and Higher Education, 20, 3550. https://doi.org/10.1016/j.iheduc.2013.10.001

Milman, N. B. (2015). Distance Education. In International Encyclopedia of the Social $\mathcal{E}$ Behavioral Sciences: Second Edition (Second Edi, Vol. 6). Elsevier. https://doi.org/10.1016/B978-0-08-097086-8.92001-4

Mulyana, Y., \& Kurniawan, A. (2019). Accounting Student Leadership Behavior: a Dilemma for Higher Education. JASS (Journal of Accounting for Sustainable Society), 1(02), 112-125. https:/ / doi.org/10.35310/jass.v1i02.246

Mustofa, M. I., Chodzirin, M., Sayekti, L., \& Fauzan, R. (2019). Formulasi Model Perkuliahan Daring Sebagai Upaya Menekan Disparitas Kualitas Perguruan Tinggi. Walisongo Journal of Information Technology, 1(2), 151-160. https:/ / doi.org/10.21580/wjit.2019.1.2.4067

Narindra, A. A. N. M., \& Budiasih, I. G. A. N. (2018). Pengaruh Perilaku Belajar Pada Tingkat Pemahaman Akuntansi Dengan Minat Belajar Dan Kepercayaan Diri Sebagai Pemediasi. E-Jurnal Ekonomi Dan Bisnis Universitas Udayana, 7(3), 903-930.

Palvia, S., Aeron, P., Gupta, P., Mahapatra, D., Parida, R., Rosner, R., \& Sindhi, S. (2018). Online Education: Worldwide Status, Challenges, Trends, and Implications. Journal of Global Information Technology Management, 21(4), 233241. https://doi.org/10.1080/1097198X.2018.1542262

Panigrahi, R., Srivastava, P. R., \& Sharma, D. (2018). Online learning: Adoption, continuance, and learning outcome-A review of literature. International Journal of Information Management, 43(May), 1-14. https://doi.org/10.1016/j.ijinfomgt.2018.05.005

Parauba, I. (2014). Pengaruh Kecerdasan Intelektual, Kecerdasan Emosional, Kecerdasan Spiritual, Dan Perilaku Belajar Terhadap Pemahaman Akuntansi Mahasiswa Fakultas Ekonomi Dan Bisnis Universitas Sam Ratulangi Manado. Jurnal Riset Akuntansi, 9(2), 53-67. https://doi.org/10.32400/gc.9.2.5059.2014

Rokhana, L. A., \& Sutrisno, S. (2016). Pengaruh Kecerdasan Emosional, Perilaku Belajar Dan Minat Belajar Terhadap Tingkat Pemahaman Akuntansi. Media Ekonomi Dan Manajemen, 31(1), 26-38.

Shyr, W. J., \& Chen, C. H. (2018). Designing a technology-enhanced flipped learning system to facilitate students' self-regulation and performance. Journal of Computer Assisted Learning, 34(1), 53-62. https://doi.org/10.1111/jcal.12213

Zaelani, R., \& Margunani. (2016). Peran Minat Belajar Sebagai Intervening Dalam Pengaruh Lingkungan Keluarga Dan Pemanfaatan Perpustakaan Sekolah Terhadap Prestasi Belajar Akuntansi. Economic Education Analysis Journal, 
$5(2), 532-545$.

Zulhawati, \& Ariani, M. (2017). Effect of learning behavior, emotional intelligence and thinking ability towards accounting understanding level. International Journal of Bio-Science and Bio-Technology, 8(5), 289-300. https://doi.org/10.14257/ijbsbt.2016.8.5.26 